\title{
Soluble Inflammatory Markers as Predictors of Hepatocellular Damage and Therapeutic Response in Chronic Hepatitis C
}

\author{
Alexandre Sampaio Moura ${ }^{1}$, Ricardo Andrade Carmo $^{2}$, Antonio Lucio Teixeira ${ }^{1}$ and Manoel Otávio da Costa Rocha ${ }^{1}$ \\ ${ }^{1}$ Postgraduate Program of Infectious Diseases and Tropical Medicine, Federal University of Minas Gerais; ${ }^{2}$ Orestes Diniz Training and Referral \\ Center for Infectious Diseases, Belo Horizonte City Health Department; Belo Horizonte, MG, Brazil
}

\begin{abstract}
Hepatitis $\mathrm{C}$ is an important burden worldwide being an important cause of cirrhosis and liver cancer in different parts of the world. Host immune response, especially T helper type 1 (Th1) cell-mediated, seems to play an important role in disease progression but is also crucial for viral elimination following specific therapy. Immune activation can be evaluated using peripheral levels of different cytokines, such as different chemokines (e.g. CCL5, CXCL10) and tumor necrosis factor alpha (TNF- $\alpha$ ), and their soluble receptors (e.g. soluble TNF- $\alpha$ receptors 1 (sTNF-R1) and 2 (sTNF-R2). This review article focuses on the potential use of peripheral inflammatory markers as predictors of liver histological changes and therapeutic response among patients with chronic hepatitis C.

Key-Words: Hepatitis C, chemokines, tumor necrosis factor receptor, interferon-alpha, liver fibrosis.
\end{abstract}

Global prevalence rates of hepatitis C virus (HCV) infection are estimated around $2 \%$ and chronic hepatitis $\mathrm{C}$ (CHC) is a major cause of cirrhosis and referral for liver transplant worldwide [1,2].

Severity of hepatocellular damage among CHC patients varies and factors such as older age at infection, male gender and alcohol intake are associated with greater inflammation and fibrosis [3,4]. Coinfection with HIV [5]or hepatitis B virus [6], steatosis [7] and insulin resistance [8] are also associated with a more rapid progression of the disease.

Assessment of liver staging in HCV-infected patients is essential to establish prognosis and the requirement for antiviral therapy. Liver biopsy is currently the gold standard for assessment of liver fibrosis but imaging techniques such as Fibroscan and panels of biochemical/hematological markers such as FibroTest or APRI (aspartate aminotransferase to platelet ratio index) are gaining acceptance [9,10]. Availability of non-invasive markers of liver fibrosis is warranted due to discomfort and risks associated with liver biopsy.

Combined treatment with interferon and ribavirin has been shown to interrupt fibrogenesis and even reverse liver fibrosis when there is a sustained virologic response [11]. Unfortunately, response rates are low, especially among genotype 1 infected patients, those at an older age or with advanced liver fibrosis [12-15]. Identifying appropriate candidates for treatment is well desired due to its high cost and potentially serious adverse effects of the currently available therapy.

The use of soluble inflammatory markers have been examined over the past ten years as predictors of both liver staging and response to therapy in CHC patients. Different chemokines, tumor necrosis factor- $\alpha$ (TNF- $\alpha$ ) and TNF- $\alpha$ soluble receptors (sTNF-R) have been showing

Received on 7 May 2009; revised 13 July 2009.

Address for correspondence: Dr. Alexandre Sampaio Moura. R. Santa Rita Durão, 41/503. Belo Horizonte - MG, Brazil. Zip code: 30140110.

The Brazilian Journal of Infectious Diseases

2009;13(5):375-382. (C) 2009 by The Brazilian Journal of Infectious Diseases and Contexto Publishing. All rights reserved. promising results in this field and will be the subject of this review.

\section{Soluble Inflammatory Markers of Liver Disease}

Hepatocellular damage in CHC patients is mainly a result of T-helper 1 (Th1) cell-mediated immune response [16,17] and is a major factor for liver fibrosis progression [18]. Th1 response is highly active in patients with chronic HCV infection and CD8+ cytotoxic T lymphocytes (CTL) has a major role in hepatocyte destruction in their attempt to clear out infection $[19,20]$. Estimating the intensity of immune activation through assessment of soluble inflammatory markers might thus help predict liver injury.

\section{Chemokines and Liver Disease}

Chemokines is a subgroup of small cytokines involved with leukocyte trafficking through a process called haptotaxis where leukocytes move towards higher concentrations of chemokines. This process is important for the regulation of leukocyte migration into sites of infection or into lymph nodes [21-27]. Chemokines are also involved in leukocyte activation, lymphocyte differentiation, regulation of Th1/Th2 balance, angiogenesis and fibrogenesis [21-27].

The more than 50 identified chemokines have been classified into four subfamilies (CC, CXC, $\mathrm{C}, \mathrm{CX}_{3} \mathrm{C}$ ) according to the position of a pair of cystein residues near their amino terminus [28]. Chemokines are named according to their subfamily followed by the letter L (for ligand) and a number corresponding to their respective gene (e.g. CCL5 or CXCL10) [29]. Nomenclature of chemokine receptors follow similar rules, with the letter $\mathrm{L}$ substituted by the letter $\mathrm{R}$ (for receptor) (e.g. CCR5, CXCR3). It is important to note that receptors are subfamily specific but usually binds more than one type of chemokine [29].

The two most important chemokine subfamilies are CXC [two cysteines separated by another amino acid (X)] and CC (two adjacent cysteines). In chronic infections, CC chemokines are more involved with monocyte attraction whereas CXC seems to be more important in directing migration of activated T lymphocytes into sites of inflammation [21,30]. 
As Th1 response is particularly involved in hepatocellular damage of CHC patients, there is special interest on chemokines responsible for the recruitment of Th1 cells into the liver. The most important of these chemokines are CCL2 (Monocyte Chemotactic Protein-1, MCP-1), CCL3 (Macrophagic Inflammatory Protein 1 alpha, MIP-1 alpha), CCL4 (Macrophagic Inflammatory Protein 1 beta, MIP-1beta), CCL5 (Regulated upon Activation, Normal T Cell Expressed and Secreted, RANTES), CXCL9 (Monokine Induced by IFNgamma, MIG) and CXCL10 (Interferon-gamma Inducible Protein, IP-10). The above mentioned CCL chemokines bind to CCR5 receptors while those CXCL chemokines bind to CXCR3 [31].

In the liver, chemokines are mainly produced by activated monocytes, Kupffer cells, endothelial cells and hepatocytes [32,33]. In accordance with the predominance of Th1 driven immune response, endothelial cells within portal tracts of $\mathrm{HCV}$ infected livers secrete CCL3, CCL4 and CCL5 and infiltrating lymphocytes express high levels of CCR5 [34]. In fact, there is greater expression of CCR5 and also of CXCR3 on liver lymphocytes as compared to circulating lymphocytes in patients with cirrhosis attributed to hepatitis C [34].

Expression of these chemokines receptors in liver lymphocytes has also been associated with hepatocellular damage. In a recent study, Larrubia et al. showed that the majority of CTL cells infiltrating the liver expressed a CCR5 $5^{\text {high/ }}$ CXCR $^{\text {high }}$ phenotype which was associated with portoperiportal and lobular inflammatory activity [35]. In accordance with these findings, mutations resulting in a less functional CCR5 were associated with less hepatic inflammation in findings of two previous studies [36,37].

Although relevant to the understanding of the mechanisms of liver inflammation in CHC, evaluation of chemokine receptors profile and/or intrahepatic chemokines levels is technically difficult to be made and cannot be widely used. However, chemokines levels can be easily assessed in peripheral serum or plasma using enzyme-linked immunosorbent assays (ELISA) that are commercially available.

Levels of peripheral chemokines usually reflect an overflow of the production at the inflammation site and are interpreted as proxies of local activity [38]. The role, if any, of these circulating plasmatic chemokines in vivo is not clear. Although they could merely represent non-functional byproducts of local production, some authors have speculated that they might antagonize leukocyte migration through downregulation of chemokine receptors in peripheral lymphocytes [35] and/or interfere with peripheral leukocyte gradient sensing [39]. This antagonism could also be explained by the fact that circulating chemokines become inactive after being processed and could compete with active chemokines for binding to leukocyte receptors [40].

Despite the uncertain role of circulating chemokines and although their levels could reflect production outside the liver [38], there is evidence that they can predict hepatocellular damage in CHC patients. CXCL10 has been widely studied in $\mathrm{CHC}$ and is among the most promising soluble inflammatory markers of liver inflammation and fibrosis.

In HCV infected liver, CXCL10 is produced by lymphoid cells, hepatocytes and endothelial cells in response to interferon-gamma, tumor necrosis factor-alpha (TNF- $\alpha$ ) and to HCV proteins such as NS5A and core [41-43]. Besides attracting monocytes and T cells, CXCL 10 also plays a role in fibrogenesis. Hepatic stellate cells (HSC), the main cell involved in liver fibrogenesis[44], express CXCR3 and has been shown to migrate following a gradient of CXCL10 [45].

The association between circulating CXCL10 levels and HCV infection was initially demonstrated in 1997 [42] in a study that showed increased serum CXCL10 levels among $\mathrm{CHC}$ patients as compared to healthy volunteers. Further studies showed that besides being elevated [38], peripheral (either serum or plasmatic) CXCL10 levels showed a doseresponse association with liver inflammation and fibrosis $[46,47]$.

Other chemokines have been studied in relation to liver histological changes in $\mathrm{CHC}$ patients. Intrahepatic expression of CXCL9, a chemokine that binds to the same receptor of CXCL10 and has similar functions, is also increased in CHC patients compared to a control group and correlates with liver inflammation $[34,48]$. Peripheral levels of CXCL9 were also significantly elevated among CHC patients compared to healthy control subjects $[38,46]$.

Peripheral levels of other chemokines from CXC subfamily, such as CXCL8 (Interleukin-8, IL-8) and CXCL11 (Interferongamma Inducible Protein-9, IP-9) are also increased among patients with CHC $[38,48]$. CXCL8 expression is stimulated by the presence of intracellular HCV non-structural proteins (e.g. NS5A) [49] and besides acting as a proinflammatory chemokine, CXCL8 exerts a proviral effect through inhibition of interferon antiviral activity [50-52]. Some authors have shown that serum CXCL8 levels increased significantly at higher histological activity and continued to increase in patients with cirrhosis [53,54]. More recently, Tachibana et al. [55] also found a correlation between serum CXCL8 levels and liver disease progression in CHC patients particularly focusing on the presence of hepatocellular carcinoma. These authors were able to show a significant increase of serum CXCL8 levels among patients with hepatocellular carcinoma, especially among those with distant metastasis [55].

Regarding chemokines from CC subfamily, intra-hepatic expression of CCL5 is increased, especially in periportal and lobular areas, and their levels of expression were significantly associated with degree of liver inflammation and aminotransferases levels [34,48,56,57]. Serum levels of CCL5 have also been associated with liver histological activity index (HAI) in CHC patients [53]. The importance of intrahepatic CCL21 expression [58] and serum CCL23 levels [59] on liver inflammation and on modulation of fibrosis has also been demonstrated. 


\section{TNF-alpha, Its Soluble Receptors and Liver Disease}

Tumor necrosis factor-alpha (TNF- $\alpha$ ) is a proinflammatory cytokine with a major role in both acute and chronic responses to viral, bacterial, fungal and parasitic infections [60]. TNF- $\alpha$ is produced primarily by activated macrophages during the inflammatory reaction that follows recognition of viral antigens, but the precise stimulus for its enhanced production in HCV infection has not been clearly defined [61].

TNF- $\alpha$ bioactivity is elicited through its binding to specific cellular receptors (TNF-R), TNF-R1 (p55) and TNF-R2 (p75) [60], that differ in molecular weight, location and function $[62,63]$. TNF-R1 has ubiquitous distribution, whilst TNF-R2 presence is more restricted, being confined mainly to cells of hematopoietic origins. TNF-R1 mediates most TNF- $\alpha$-induced cellular responses, including activation of transcription factors like NF- $\kappa B$ and apoptosis [64,65].

These membrane receptors can suffer proteolytic cleavage and become soluble receptors that bind circulating TNF- $\alpha$ and inhibit its activity [66-70]. This inhibition is a result of competition between soluble and membrane receptors for TNF$\alpha$ binding and has an important role in regulating TNF- $\alpha$ bioactivity [71]. Soluble TNF receptors (sTNF-R1 and sTNFR2) are released from activated neutrophils, mononuclear blood cells and fibroblasts[72-74] in response to different substances such as bacterial or viral products, and several cytokines (IL-10,IL-2, IL-6, GM-CSF) including TNF- $\alpha$ itself [72,75-77].

TNF- $\alpha$ has been involved in the pathogenesis of several liver conditions including viral hepatitis [65,78]. In patients with hepatitis C, TNF- $\alpha$ is an inducer of apoptosis in infected hepatocytes [79] and might also account for CTL damage to nearby non-infected hepatocytes [54].

Serum TNF- $\alpha$ levels correlate well with its liver immunohistochemical pattern suggesting that peripheral levels could be used as surrogate markers of local TNF expression in CHC patients [53]. Serum TNF- $\alpha$ levels are significantly higher among patients with CHC compared to healthy volunteers [80] and are positively associated with aminotransferase levels [81] and both inflammation and fibrosis in liver biopsies [82]. Even patients with mild liver inflammation have elevated serum TNF- $\alpha$ levels suggesting that this cytokine could be used as a sensitive predictor of liver inflammation [83]. Elevated serum levels of TNF- $\alpha$ have also been associated with hepatic steatosis [84], a known risk factor for disease progression among CHC patients [85,86], possibly due to their correlation with low levels of adiponectin, an important regulator of hepatic lipid content [84].

Circulating sTNF-R levels seems to reflect activation of the TNF system [87] although it is not clear whether these soluble receptors come from liver and/or from peripheral blood mononuclear cells [65]. As sTNF-R have higher stability and longer half-life than those of circulating TNF they have been considered even better markers of liver inflammatory activity [88].

In patients with hepatitis $\mathrm{C}$, serum levels of soluble TNF receptors (sTNF-R1 and sTNF-R2) were significantly higher if compared to control subjects and were associated with aminotransferases levels and both inflammation and fibrosis in liver biopsies [65,89-91].

\section{Soluble Inflammatory Markers and Treatment Response}

Current standard therapy for CHC patients is based on a combination of pegylated interferon- $\alpha$ (IFN- $\alpha$ ) and ribavirin (RBV) for 24 or 48 weeks depending on viral genotype [92,93].

Exogenous IFN- $\alpha$ acts similarly to its endogenous counterpart through induction IFN-stimulated genes (ISGs) responsible for establishing an antiviral state within the cell $[94,95]$. In addition to its direct antiviral activity, IFN- $\alpha$ strengthens both innate and adaptive immune response through interaction with T lymphocytes, NK cells and dendritic cells [95].

Ribavirin, a guanosine-analogue, seems to work as an antiviral agent mainly by inducing HCV mutagenesis that results in a lower replicative fitness [94]. Acting also as an immunomodulator, ribavirin enhances Th1 cytokine secretion altering Th1/Th2 balance in favor of a Th1 response [96].

Sustained responses (i.e. negative HCV qualitative PCR 24 weeks after the end of treatment) are observed in around half of treated patients and many factors such as age, genotype, viral load and body weight are related with treatment outcome [12,13]. Outcome of HCV treatment seems also to depend on the ability of host cellular immune response to control viral replication. An early Th1 response is key to viral clearance during acute HCV infection [97-99]and an enhanced HCV-specific T-cell response is also associated with treatment response among chronically infected patients [99102]. Therefore, it is reasonable to suppose that pretreatment and on-treatment levels of cytokines, especially those involved with Th1 response, might help predict treatment outcome.

\section{Chemokine Levels and Treatment Response}

Chemoattraction of CTL to the liver seems essential to HCV eradication. As chemokines regulate the movement of leukocytes throughout the body they seem to play a key role in treatment response.

As already mentioned, CCL3, CCL4 and CCL5, through their interaction with CCR5 in leukocytes, are very important to the immune response against HCV [34]. A decreased CCR5 expression reduce Th1 cytokine responses in CHC patients $[103,104]$ and might thus impair treatment response. CCR5 expression is up-regulated by interferon [105] and inhibited by HCV envelope protein E2 [106].

In order to better study the CCR5 role in the treatment of CHC patients, some studies have been conducted among patients with mutations that preclude expression of a functional CCR5. These studies has shown that patients with CCR5-Delta 32 mutation were associated with a decreased response to IFN- $\alpha$ monotherapy[107], although this difference was not observed when the more potent combination of interferon and ribavirin was used [108]. 
CXCR3 is another receptor expressed by effector Th1 cells [109] and an increase in CXCR3 ${ }^{\text {high }}$ CTL is associated with sustained viral response [35]. This latter study has shown that all patients who failed to increase CXCR3 ${ }^{\text {high }}$ expressing CTL after 24 weeks of treatment also failed to achieve sustained viral response [35].

Pretreatment peripheral levels of one of the CXCR3 ligands, CXCL10, were inversely correlated with response to therapy either with interferon alone [38] or in combination with ribavirin $[46,110]$. The association between peripheral CXCL10 levels and treatment outcome was shown for both standard [42] and pegylated interferon $[38,46,111,112]$ with higher pretreatment levels being independently associated with poorer response rates. The association was shown for either rapid virologic response (RVR) and sustained virologic response (SVR) [111,112]. Two different studies showed that CXCL10 peripheral levels greater than $600 \mathrm{pg} / \mathrm{mL}$ yielded an overall negative predicted value for SVR of around 80\% that reached 100\% in difficult to treat patients (e.g. high body mass index and high viral load) [111,112].

Kinetics of CXCL10 levels during treatment were also predictors of response. Narumi et al. [42] have shown that a reduction on CXCL10 serum levels precedes therapeutic response and sustained responder completely normalize them. In another study, Itoh et al. [113] showed that patients who did not clear the HCV after treatment maintained higher serum levels of CXCL-10 compared to virological responders even if they were able to normalize transaminases levels after treatment, i.e. have had a biochemical response.

Different theories had been presented to explain the relationship between elevated levels of CXCL10 and poor response rates. High peripheral levels of CXCL10 could impair local CCL5 or CXCL10 gradient signaling [38] or could downregulate CXCR5 receptors in circulating CTL [35]. A different explanation was proposed by Diago et al. assuming that elevated CXCL10 levels would result in accumulation of effector $\mathrm{T}$ cells in the liver [110]. The selective pressure imposed by this accumulation would foster outgrowth of immune escape HCV mutants that could be more difficult to eradicate with combined therapy [110].

Levels of other two CXCR ligands, CXCL9 and CXCL11, have also been studied as predictors of treatment response in CHC patients. Plasmatic levels of CXCL9 had a significant decline on patients with sustained virological responses but pretreatment levels were not associated with response rates [38]. The same study did not show any association between pretreatment plasmatic levels of CXCL11 and response rates nor any changes in their levels during treatment [38].

CXCL8, a chemokine that binds to CXCR1 and to CXCR2, is responsible mainly for neutrophils recruitment and, as already mentioned, is involved in inhibition of interferon action. In accordance with this inhibitory role, serum CXCL8 levels were higher in hepatitis $\mathrm{C}$ patients who fail to respond to antiviral therapy compared to patients with sustained responses [52,114,115].
Kinetics of CC chemokines during treatment of CHC patients has also been studied. Yamauchi et al. [59] have shown that serum CCL23 levels increased two weeks after starting therapy and returned to pre-treatment levels two weeks later among responders whereas non-responder did not have any significantly change in CCL23 levels. However, baseline CCL23 levels were similar comparing responders to non-responders and were not useful as predictors of response [59].

The role of CCL2 and its receptor, CCR2, as predictors of treatment response among CHC patients is less clear. One study has demonstrated an association between kinetics of serum levels of CCL2 and response rates [116] but other recent study failed to show any association between CCR2 and CCL2 gene polymorphisms and sustained virological response [117]

\section{TNF- $\alpha$, Its Soluble Receptors and Treatment Response}

TNF- $\alpha$ does not affect HCV RNA or protein synthesis and, therefore, it does not seem to be directly involved in HCV clearance [118]. TNF synthesis is suppressed by IFN- $\alpha$ during HCV treatment [119] and the inhibition of TNF- $\alpha$ activity is considered to be one of the mechanisms through which normalization of aminotransferases occurs even with persistence of infection during treatment [120].

Among patients with $\mathrm{CHC}$ receiving combined treatment with IFN- $\alpha$ and ribavirin, serum TNF- $\alpha$ levels significantly decreased at the end of treatment and the decline paralleled those observed with aminotransferase levels [80]. Among responders, lower TNF- $\alpha$ levels were sustained during follow up, whereas among relapsers TNF- $\alpha$ returned to pre-treatment levels. The fall of TNF- $\alpha$ was greater at the end of treatment among those who received combined therapy as compared to those receiving IFN- $\alpha$ monotherapy suggesting an additional role of ribavirin in TNF- $\alpha$ supression.[121, 122]

Although IFN- $\alpha$ reduces TNF- $\alpha$ expression even further, patients who already have lower serum pretreatment levels of TNF- $\alpha$ [115] or lower levels of TNF- $\alpha$ mRNA expression in peripheral blood mononuclear cells (PBMC) [123] had better response rates to IFN- $\alpha$ treatment. In a double blind, placebo controlled clinical trial, the use of etanercept, a TNF- $\alpha$ antagonist, in the first 24 weeks of a 48-week IFN- $\alpha$ and ribavirin treatment, resulted in higher virological on-treatment response rates [124]. It is important to note however that another study did not show any difference between pretreatment serum levels of TNF among responders and nonresponders to IFN- $\alpha$ monotherapy [65], thus questioning the use of serum TNF levels as treatment predictors.

Soluble TNF receptors (sTNF-R) might contribute to the anti-inflammatory action of IFN- $\alpha$. In hepatitis B virus infection, elevated serum levels of sTNF-R before interferon therapy were found to predict a successful response to treatment [125]. In hepatitis $\mathrm{C}$, the role of sTNF-R is still not clear. One study has shown an increase in sTNF-R, especially sTNF-R1, after IFN- $\alpha$ administration [82], but others did not show any elevation of sTNF-R with treatment and did not find any relationship between response rates and pre-treatment levels 
of neither TNF nor sTNF-R $[65,89]$. A study has shown that levels of sTNF-R2 decreased after treatment in sustained responders to IFN- $\alpha$ monotherapy [91] whereas another study with similar therapeutic regimen but much fewer patients did not show any change in sTNF-R levels during IFN- $\alpha$ monotherapy [90]. Considering the characteristics of sTNF$\mathrm{R}$, including its greater stability in peripheral circulation, further studies are warranted to better understand the role of sTNF$\mathrm{R}$ in predicting treatment response.

\section{Future Perspectives}

Although the origin and mechanism of action of circulating soluble inflammatory markers are not perfectly understood, they might be useful as predictors of both hepatocellular damage and treatment response in patients with chronic hepatitis C. Application of these markers in the clinical setting will depend on standardization of methods used for cytokine measurement as well as availability of reliable commercial kits for this purpose. Further studies correlating or aggregating these serum inflammatory markers with other non-invasive methods of liver staging, such as Fibrotest and Fibroscan are needed. Studies on the role of these inflammatory markers as predictors of response among treatment-experienced patients being retreated with new molecules, such as polymerase or protease inhibitors [126], would also be interesting.

\section{References}

1. Shepard C.W., Finelli L., Alter M.J. Global epidemiology of hepatitis C virus infection. Lancet Infect Dis 2005; 5: 558-67.

2. Perz J.F., Armstrong G.L., Farrington L.A., et al. The contributions of hepatitis $B$ virus and hepatitis $C$ virus infections to cirrhosis and primary liver cancer worldwide. J Hepatol 2006; 45: 529-38.

3. Poynard T., Bedossa P., Opolon P. Natural history of liver fibrosis progression in patients with chronic hepatitis C. The OBSVIRC, METAVIR, CLINIVIR, and DOSVIRC groups. Lancet 1997; 349: 825-32.

4. Poynard T., Ratziu V., Charlotte F., et al. Rates and risk factors of liver fibrosis progression in patients with chronic hepatitis C. J Hepatol 2001; 34: 730-9.

5. Benhamou Y., Bochet M., Di Martino V., et al. Liver fibrosis progression in human immunodeficiency virus and hepatitis $\mathrm{C}$ virus coinfected patients. The Multivirc Group. Hepatology 1999; 30: 1054-8.

6. Benvegnu L., Fattovich G., Noventa F., et al. Concurrent hepatitis $\mathrm{B}$ and $\mathrm{C}$ virus infection and risk of hepatocellular carcinoma in cirrhosis. A prospective study. Cancer 1994; 74: 2442-8.

7. Leandro G., Mangia A., Hui J., et al. Relationship between steatosis, inflammation, and fibrosis in chronic hepatitis C: a meta-analysis of individual patient data. Gastroenterology 2006; 130: 1636-42.

8. Hui J.M., Sud A., Farrell G.C., et al. Insulin resistance is associated with chronic hepatitis $\mathrm{C}$ virus infection and fibrosis progression. Gastroenterology 2003; 125: 1695-704.

9. Shaheen A.A., Wan A.F., Myers R.P. FibroTest and FibroScan for the prediction of hepatitis C-related fibrosis: a systematic review of diagnostic test accuracy. Am J Gastroenterol 2007; 102: 2589-600.

10. Wai C.T., Greenson J.K., Fontana R.J., et al. A simple noninvasive index can predict both significant fibrosis and cirrhosis in patients with chronic hepatitis C. Hepatology 2003; 38: 518-26.

11. Poynard T., McHutchison J., Manns M., et al. Impact of pegylated interferon alfa-2b and ribavirin on liver fibrosis in patients with chronic hepatitis C. Gastroenterology 2002; 122: 1303-13.
12. Fried M.W., Shiffman M.L., Reddy K.R., et al. Peginterferon alfa2a plus ribavirin for chronic hepatitis $\mathrm{C}$ virus infection. $\mathrm{N}$ Engl J Med 2002; 347: 975-82.

13. Manns M.P., McHutchison J.G., Gordon S.C., et al. Peginterferon alfa-2b plus ribavirin compared with interferon alfa-2b plus ribavirin for initial treatment of chronic hepatitis C: a randomised trial. Lancet 2001; 358: 958-65.

14. Lee S.S., Heathcote E.J., Reddy K.R., et al. Prognostic factors and early predictability of sustained viral response with peginterferon alfa-2a (40KD). J Hepatol 2002; 37: 500-6.

15. Mihm U., Herrmann E., Sarrazin C, Zeuzem S. Review article: predicting response in hepatitis $\mathrm{C}$ virus therapy. Aliment Pharmacol Ther 2006; 23: 1043-54.

16. Napoli J., Bishop G.A., McGuinness P.H., et al. Progressive liver injury in chronic hepatitis $C$ infection correlates with increased intrahepatic expression of Th1-associated cytokines. Hepatology 1996; 24: 759-65.

17. Sobue S., Nomura T., Ishikawa T., et al. Th1/Th2 cytokine profiles and their relationship to clinical features in patients with chronic hepatitis C virus infection. J Gastroenterol 2001; 36: 544-51.

18. Ghany M.G., Kleiner D.E., Alter H., et al. Progression of fibrosis in chronic hepatitis C. Gastroenterology 2003; 124: 97-104.

19. Chang K.M., Rehermann B., Chisari F.V. Immunopathology of hepatitis C. Springer Semin Immunopathol 1997; 19: 57-68.

20. Wejstal R. Immune-mediated liver damage in chronic hepatitis C. Scand J Gastroenterol 1995; 30: 609-13.

21. Luster A.D. Chemokines-chemotactic cytokines that mediate inflammation. N Engl J Med 1998; 338: 436-45.

22. Baggiolini M., Dewald B., Moser B. Human chemokines: an update. Annu Rev Immunol 1997; 15: 675-705.

23. Mackay C.R. Chemokines: what chemokine is that? Curr Biol 1997; 7: R384-6.

24. Gerard C., Rollins B.J. Chemokines and disease. Nat Immunol 2001; 2: 108-15.

25. Kunkel S.L. Through the looking glass: the diverse in vivo activities of chemokines. J Clin Invest 1999; 104: 1333-4.

26. Charo I.F., Ransohoff R.M. The many roles of chemokines and chemokine receptors in inflammation. $\mathrm{N}$ Engl J Med 2006; 354: 610-21.

27. Ono S.J., Nakamura T., Miyazaki D., et al. Chemokines: roles in leukocyte development, trafficking, and effector function. J Allergy Clin Immunol 2003; 111: 1185-99.

28. Rot A., von Andrian U.H. Chemokines in innate and adaptive host defense: basic chemokinese grammar for immune cells. Annu Rev Immunol 2004; 22: 891-928.

29. Zlotnik A.Yoshie O. Chemokines: a new classification system and their role in immunity. Immunity 2000; 12: 121-7.

30. Rollins B.J. Chemokines. Blood 1997; 90: 909-28.

31. Bonecchi R., Bianchi G., Bordignon P.P., et al. Differential expression of chemokine receptors and chemotactic responsiveness of type $1 \mathrm{~T}$ helper cells (Th1s) and Th2s. J Exp Med 1998; 187: 129-34.

32. Koziel M.J. Cytokines in viral hepatitis. Seminars in liver disease 1999; 19: 157-69.

33. Apolinario A., Garcia Monzon C. Role of chemokines in the pathogenesis of liver diseases. Rev Esp Enferm Dig 2003; 95: 614-20, 07-13.

34. Shields P.L., Morland C.M., Salmon M., et al. Chemokine and chemokine receptor interactions provide a mechanism for selective $\mathrm{T}$ cell recruitment to specific liver compartments within hepatitis C-infected liver. J Immunol 1999; 163: 6236-43.

35. Larrubia J.R., Calvino M., Benito S., et al. The role of CCR5/ CXCR3 expressing CD8+ cells in liver damage and viral control during persistent hepatitis C virus infection. J Hepatol 2007; 47: 632-41.

36. Goulding C., McManus R., Murphy A., et al. The CCR5-delta32 mutation: impact on disease outcome in individuals with hepatitis C infection from a single source. Gut 2005; 54: 1157-61. 
37. Hellier S., Frodsham A.J., Hennig B.J., et al. Association of genetic variants of the chemokine receptor CCR5 and its ligands, RANTES and MCP-2, with outcome of HCV infection. Hepatology 2003; 38: 1468-76.

38. Butera D., Marukian S., Iwamaye A.E., et al. Plasma chemokine levels correlate with the outcome of antiviral therapy in patients with hepatitis C. Blood 2005; 106: 1175-82.

39. Hechtman D.H., Cybulsky M.I., Fuchs H.J., et al. Intravascular IL-8. Inhibitor of polymorphonuclear leukocyte accumulation at sites of acute inflammation. J Immunol 1991; 147: 883-92.

40. Clark-Lewis I., Mattioli I., Gong J.H., Loetscher P. Structurefunction relationship between the human chemokine receptor CXCR3 and its ligands. J Biol Chem 2003; 278: 289-95.

41. Narumi S., Yoneyama H., Inadera H., et al. TNF-alpha is a potent inducer for IFN-inducible protein-10 in hepatocytes and unaffected by GM-CSF in vivo, in contrast to IL-1beta and IFN-gamma. Cytokine 2000; 12: 1007-16.

42. Narumi S., Tominaga Y., Tamaru M., et al. Expression of IFNinducible protein-10 in chronic hepatitis. J Immunol 1997; 158: 5536-44.

43. Apolinario A., Majano P.L., Lorente R., et al. Gene expression profile of T-cell-specific chemokines in human hepatocytederived cells: evidence for a synergistic inducer effect of cytokines and hepatitis C virus proteins. J Viral Hepat 2005; 12: $27-37$

44. Iredale J.P. Cirrhosis: new research provides a basis for rational and targeted treatments. BMJ 2003; 327: 143-7.

45. Bonacchi A., Romagnani P., Romanelli R.G., et al. Signal transduction by the chemokine receptor CXCR3: activation of Ras/ERK, Src, and phosphatidylinositol 3-kinase/Akt controls cell migration and proliferation in human vascular pericytes. J Biol Chem 2001; 276: 9945-54.

46. Apolinario A., Diago M., Lo Iacono O., et al. Increased circulating and intrahepatic T-cell-specific chemokines in chronic hepatitis C: relationship with the type of virological response to peginterferon plus ribavirin combination therapy. Aliment Pharmacol Ther 2004; 19: 551-62.

47. Harvey C.E., Post J.J., Palladinetti P., et al. Expression of the chemokine IP-10 (CXCL10) by hepatocytes in chronic hepatitis $\mathrm{C}$ virus infection correlates with histological severity and lobular inflammation. J Leukoc Biol 2003; 74: 360-9.

48. Apolinario A., Majano P.L., Alvarez-Perez E., et al. Increased expression of $\mathrm{T}$ cell chemokines and their receptors in chronic hepatitis C: relationship with the histological activity of liver disease. Am J Gastroenterol 2002; 97: 2861-70.

49. Wertheimer A.M., Polyak S.J., Leistikow R, Rosen H.R. Engulfment of apoptotic cells expressing HCV proteins leads to differential chemokine expression and STAT signaling in human dendritic cells. Hepatology 2007; 45: 1422-32.

50. Khabar K.S., Al-Zoghaibi F., Al-Ahdal M.N., et al. The alpha chemokine, interleukin 8 , inhibits the antiviral action of interferon alpha. J Exp Med 1997; 186: 1077-85.

51. Polyak S.J., Khabar K.S., Paschal D.M., et al. Hepatitis C virus nonstructural 5A protein induces interleukin-8, leading to partial inhibition of the interferon-induced antiviral response. J Virol 2001; 75: 6095-106.

52. Polyak S.J., Khabar K.S., Rezeiq M.Gretch D.R. Elevated levels of interleukin-8 in serum are associated with hepatitis C virus infection and resistance to interferon therapy. J Virol 2001; 75: 6209-11.

53. Neuman M.G., Benhamou J.P., Marcellin P., et al. Cytokinechemokine and apoptotic signatures in patients with hepatitis C. Transl Res 2007; 149: 126-36.

54. Kaplanski G., Farnarier C., Payan M.J., et al. Increased levels of soluble adhesion molecules in the serum of patients with hepatitis C. Correlation with cytokine concentrations and liver inflammation and fibrosis. Dig Dis Sci 1997; 42: 2277-84.
55. Tachibana Y., Nakamoto Y., Mukaida N.Kaneko S. Intrahepatic interleukin-8 production during disease progression of chronic hepatitis C. Cancer Lett 2007; 251: 36-42.

56. Kusano F., Tanaka Y., Marumo F.Sato C. Expression of C-C chemokines is associated with portal and periportal inflammation in the liver of patients with chronic hepatitis C. Lab Invest 2000; 80: 415-22.

57. Nischalke H.D., Nattermann J., Fischer H.P., et al. Semiquantitative analysis of intrahepatic CC-chemokine mRNas in chronic hepatitis C. Mediators Inflamm 2004; 13: 357-9.

58. Bonacchi A., Petrai I., Defranco R.M., et al. The chemokine CCL21 modulates lymphocyte recruitment and fibrosis in chronic hepatitis C. Gastroenterology 2003; 125: 1060-76.

59. Yamauchi K., Akbar S.M., Horiike N., et al. Increased serum levels of macrophage inflammatory protein-3alpha in chronic viral hepatitis: prognostic importance of macrophage inflammatory protein-3alpha during interferon therapy in chronic hepatitis C. J Viral Hepat 2002; 9: 213-20.

60. Bradley J.R. TNF-mediated inflammatory disease. J Pathol 2008; 214: $149-60$

61. Radkowski M., Bednarska A., Horban A., et al. Infection of primary human macrophages with hepatitis $\mathrm{C}$ virus in vitro: induction of tumour necrosis factor-alpha and interleukin 8. J Gen Virol 2004; 85: 47-59.

62. Gehr G., Gentz R., Brockhaus M., et al. Both tumor necrosis factor receptor types mediate proliferative signals in human mononuclear cell activation. J Immunol 1992; 149: 911-7.

63. Ware C.F., Crowe P.D., Vanarsdale T.L., et al. Tumor necrosis factor (TNF) receptor expression in $\mathrm{T}$ lymphocytes. Differential regulation of the type I TNF receptor during activation of resting and effector T cells. J Immunol 1991; 147: 4229-38.

64. Liu Z.G., Han J. Cellular responses to tumor necrosis factor. Curr Issues Mol Biol 2001; 3: 79-90.

65. Kallinowski B., Haseroth K., Marinos G., et al. Induction of tumour necrosis factor (TNF) receptor type p55 and p75 in patients with chronic hepatitis C virus (HCV) infection. Clin Exp Immunol 1998; 111: 269-77.

66. Nophar Y., Kemper O., Brakebusch C., et al. Soluble forms of tumor necrosis factor receptors (TNF-Rs). The cDNA for the type I TNF-R, cloned using amino acid sequence data of its soluble form, encodes both the cell surface and a soluble form of the receptor. EMBO J 1990; 9: 3269-78.

67. Engelmann H., Novick D.Wallach D. Two tumor necrosis factorbinding proteins purified from human urine. Evidence for immunological cross-reactivity with cell surface tumor necrosis factor receptors. J Biol Chem 1990; 265: 1531-6.

68. Olsson I., Lantz M., Nilsson E., et al. Isolation and characterization of a tumor necrosis factor binding protein from urine. Eur J Haematol 1989; 42: 270-5.

69. Seckinger P., Isaaz S.Dayer J.M. Purification and biologic characterization of a specific tumor necrosis factor alpha inhibitor. J Biol Chem 1989; 264: 11966-73.

70. Wang J., Al-Lamki R.S., Zhang H., et al. Histamine antagonizes tumor necrosis factor (TNF) signaling by stimulating TNF receptor shedding from the cell surface and Golgi storage pool. J Biol Chem 2003; 278: 21751-60.

71. Aderka D. The potential biological and clinical significance of the soluble tumor necrosis factor receptors. Cytokine Growth Factor Rev 1996; 7: 231-40.

72. Porteu F., Nathan C. Shedding of tumor necrosis factor receptors by activated human neutrophils. J Exp Med 1990; 172: 599-607.

73. Porteu F., Brockhaus M., Wallach D., et al. Human neutrophil elastase releases a ligand-binding fragment from the 75-kDa tumor necrosis factor (TNF) receptor. Comparison with the proteolytic activity responsible for shedding of TNF receptors from stimulated neutrophils. J Biol Chem 1991; 266: 18846-53. 
74. Porteu F.Hieblot C. Tumor necrosis factor induces a selective shedding of its p75 receptor from human neutrophils. J Biol Chem 1994; 269: 2834-40.

75. Lien E., Liabakk N.B., Johnsen A.C., et al. Polymorphonuclear granulocytes enhance lipopolysaccharide-induced soluble p75 tumor necrosis factor receptor release from mononuclear cells. Eur J Immunol 1995; 25: 2714-7.

76. Joyce D.A., Gibbons D.P., Green P., et al. Two inhibitors of proinflammatory cytokine release, interleukin-10 and interleukin4 , have contrasting effects on release of soluble p75 tumor necrosis factor receptor by cultured monocytes. Eur J Immunol 1994; 24: 2699-705.

77. Lantz M., Malik S., Slevin M.L.Olsson I. Infusion of tumor necrosis factor (TNF) causes an increase in circulating TNF-binding protein in humans. Cytokine 1990; 2: 402-6.

78. Yoshioka K., Kakumu S., Arao M., et al. Tumor necrosis factor alpha production by peripheral blood mononuclear cells of patients with chronic liver disease. Hepatology 1989; 10: 76973.

79. Kountouras J., Zavos C.Chatzopoulos D. Apoptosis in hepatitis C. J Viral Hepat 2003; 10: 335-42.

80. Neuman M.G., Benhamou J.P., Malkiewicz I.M., et al. Cytokines as predictors for sustained response and as markers for immunomodulation in patients with chronic hepatitis C. Clin Biochem 2001; 34: 173-82.

81. Hassan M.I., Kassim S.K., Ahmad M.I.Fawzy S. Antiproliferative effect of hepatitis $\mathrm{C}$ virus on mitogenstimulated peripheral blood mononuclear cells: potential role in viral persistence in Egyptian patients. Clin Biochem 2007; 40: 1173-9.

82. Tilg H., Vogel W.Dinarello C.A. Interferon-alpha induces circulating tumor necrosis factor receptor p55 in humans. Blood 1995; 85: 433-5.

83. Neuman M.G., Benhamou J.P., Malkiewicz I.M., et al. Kinetics of serum cytokines reflect changes in the severity of chronic hepatitis C presenting minimal fibrosis. J Viral Hepat 2002; 9: 134-40.

84. Durante-Mangoni E., Zampino R., Marrone A., et al. Hepatic steatosis and insulin resistance are associated with serum imbalance of adiponectin/tumour necrosis factor-alpha in chronic hepatitis $C$ patients. Aliment Pharmacol Ther 2006; 24: 1349-57.

85. Adinolfi L.E., Gambardella M., Andreana A., et al. Steatosis accelerates the progression of liver damage of chronic hepatitis C patients and correlates with specific HCV genotype and visceral obesity. Hepatology 2001; 33: 1358-64.

86. Hourigan L.F., Macdonald G.A., Purdie D., et al. Fibrosis in chronic hepatitis C correlates significantly with body mass index and steatosis. Hepatology 1999; 29: 1215-9.

87. Diez-Ruiz A., Tilz G.P., Zangerle R., et al. Soluble receptors for tumour necrosis factor in clinical laboratory diagnosis. Eur $\mathrm{J}$ Haematol 1995; 54: 1-8.

88. Van Zee K.J., Kohno T., Fischer E., et al. Tumor necrosis factor soluble receptors circulate during experimental and clinical inflammation and can protect against excessive tumor necrosis factor alpha in vitro and in vivo. Proc Natl Acad Sci U S A 1992; 89: 4845-9.

89. Zylberberg H., Rimaniol A.C., Pol S., et al. Soluble tumor necrosis factor receptors in chronic hepatitis C: a correlation with histological fibrosis and activity. J Hepatol 1999; 30: 185-91.

90. Kakumu S., Okumura A., Ishikawa T., et al. Serum levels of IL-10, IL-15 and soluble tumour necrosis factor-alpha (TNF-alpha) receptors in type $\mathrm{C}$ chronic liver disease. Clin Exp Immunol 1997; 109: 458-63.

91. Itoh Y., Okanoue T., Ohnishi N., et al. Serum levels of soluble tumor necrosis factor receptors and effects of interferon therapy in patients with chronic hepatitis $\mathrm{C}$ virus infection. American J Gastroenterol 1999; 94: 1332-40.
92. Strader D.B., Wright T., Thomas D.L.Seeff L.B. Diagnosis, management, and treatment of hepatitis C. Hepatology 2004; 39: 1147-71.

93. de Araujo E.S., Mendonca J.S., Barone A.A., et al. Consensus of the Brazilian Society of Infectious Diseases on the management and treatment of hepatitis C. Braz J Infect Dis 2007; 11: 446-50.

94. Feld J.J., Hoofnagle J.H. Mechanism of action of interferon and ribavirin in treatment of hepatitis C. Nature 2005; 436: 967-72.

95. Tilg $\mathrm{H}$. New insights into the mechanisms of interferon alfa: an immunoregulatory and anti-inflammatory cytokine. Gastroenterology 1997; 112: 1017-21.

96. Tam R.C., Pai B., Bard J., et al. Ribavirin polarizes human T cell responses towards a Type 1 cytokine profile. J Hepatol 1999; 30: 376-82.

97. Guidotti L.G., Chisari F.V. Noncytolytic control of viral infections by the innate and adaptive immune response. Ann Rev Immunol 2001; 19: 65-91.

98. Rehermann B., Nascimbeni M. Immunology of hepatitis B virus and hepatitis $C$ virus infection. Nat Rev Immunol 2005; 5: 215-29.

99. Kamal S.M., Ismail A., Graham C.S., et al. Pegylated interferon alpha therapy in acute hepatitis C: relation to hepatitis C virus-specific $\mathrm{T}$ cell response kinetics. Hepatology 2004; 39: 1721-31.

100.Kamal S.M., Fehr J., Roesler B., et al. Peginterferon alone or with ribavirin enhances HCV-specific CD4 T-helper 1 responses in patients with chronic hepatitis C. Gastroenterology 2002; 123: 1070-83.

101.Cramp M.E., Rossol S., Chokshi S., et al. Hepatitis C virusspecific $\mathrm{T}$-cell reactivity during interferon and ribavirin treatment in chronic hepatitis C. Gastroenterology 2000; 118: 346-55.

102.Nelson D.R., Marousis C.G., Ohno T., et al. Intrahepatic hepatitis $\mathrm{C}$ virus-specific cytotoxic $\mathrm{T}$ lymphocyte activity and response to interferon alfa therapy in chronic hepatitis C. Hepatology 1998; 28: 225-30.

103.Lechner F., Gruener N.H., Urbani S., et al. CD8+ T lymphocyte responses are induced during acute hepatitis $\mathrm{C}$ virus infection but are not sustained. Eur J Immunol 2000; 30: 2479-87.

104.Woitas R.P., Lechmann M., Jung G., et al. CD30 induction and cytokine profiles in hepatitis $C$ virus core-specific peripheral blood T lymphocytes. J Immunol 1997; 159: 1012-8.

105. Yang Y.F., Tomura M., Iwasaki M., et al. IFN-alpha acts on Tcell receptor-triggered human peripheral leukocytes to upregulate CCR5 expression on CD4+ and CD8+ T cells. J Clin Immunol 2001; 21: 402-9.

106.Nattermann J., Nischalke H.D., Feldmann G., et al. Binding of HCV E2 to CD81 induces RANTES secretion and internalization of CC chemokine receptor 5. J Viral Hepat 2004; 11: 519-26.

107.Ahlenstiel G., Berg T., Woitas R.P., et al. Effects of the CCR5Delta32 mutation on antiviral treatment in chronic hepatitis C. J Hepatol 2003; 39: 245-52.

108.Glas J., Torok H.P., Simperl C., et al. The Delta 32 mutation of the chemokine-receptor 5 gene neither is correlated with chronic hepatitis $\mathrm{C}$ nor does it predict response to therapy with interferon-alpha and ribavirin. Clin Immunol 2003; 108: $46-50$.

109.von Andrian U.H.Mackay C.R. T-cell function and migration. Two sides of the same coin. N Engl J Med 2000; 343: 102034.

110.Diago M., Castellano G., Garcia-Samaniego J., et al. Association of pretreatment serum interferon gamma inducible protein 10 levels with sustained virological response to peginterferon plus ribavirin therapy in genotype 1 infected patients with chronic hepatitis C. Gut 2006; 55: 374-9. 
111.Romero A.I., Lagging M., Westin J., et al. Interferon (IFN)gamma-inducible protein-10: association with histological results, viral kinetics, and outcome during treatment with pegylated IFN-alpha 2a and ribavirin for chronic hepatitis C virus infection. J Infect Dis 2006; 194: 895-903.

112.Lagging M., Romero A.I., Westin J., et al. IP-10 predicts viral response and therapeutic outcome in difficult-totreat patients with HCV genotype 1 infection. Hepatology 2006; 44: 1617-25.

113.Itoh Y., Morita A., Nishioji K., et al. Clinical significance of elevated serum interferon- inducible protein-10 levels in hepatitis C virus carriers with persistently normal serum transaminase levels. J Viral Hepat 2001; 8: 341-8.

114.Mihm U., Herrmann E., Sarrazin U., et al. Association of serum interleukin-8 with virologic response to antiviral therapy in patients with chronic hepatitis C. J Hepatol 2004; 40: 845-52.

115.Neuman M.G., Benhamou J.P., Martinot M., et al. Predictors of sustained response to alpha interferon therapy in chronic hepatitis C. Clin Biochem 1999; 32: 537-45.

116.Panasiuk A., Prokopowicz D., Panasiuk B. Monocyte chemotactic protein-1 and soluble adhesion molecules as possible prognostic markers of the efficacy of antiviral treatment in chronic hepatitis C. World J Gastroenterol 2004; 10: 3639-42.

117. Montes-Cano M.A., Garcia-Lozano J.R., Aguilar-Reina J., et al. CCL2-2518 A/G and CCR2 190 A/G do not influence the outcome of hepatitis $\mathrm{C}$ virus infection in the Spanish population. World J Gastroenterol 2007; 13: 2187-92.

118.Frese M., Barth K., Kaul A., et al. Hepatitis C virus RNA replication is resistant to tumour necrosis factor-alpha. J Gen Virol 2003; 84: 1253-9.
119.Abu-Khabar K.S., Armstrong J.A., Ho M. Type I interferons (IFN-alpha and -beta) suppress cytotoxin (tumor necrosis factor-alpha and lymphotoxin) production by mitogenstimulated human peripheral blood mononuclear cell. J Leukoc Biol 1992; 52: 165-72.

120.Fabris C., Del Forno M., Falleti E., et al. Kinetics of serum soluble tumour necrosis factor receptor (TNF-R) type-I and type-II after a single interferon-alpha (IFN-alpha) injection in chronic hepatitis C. Clin Exp Immunol 1999; 117: 55660.

121.Neuman M.G., Benhamou J.P., Bourliere M., et al. Serum tumour necrosis factor-alpha and transforming growth factor-beta levels in chronic hepatitis $\mathrm{C}$ patients are immunomodulated by therapy. Cytokine 2002; 17: 108-17.

122.Neuman M.G., Benhamou J.P., Ibrahim A., et al. Role of cytokines in the assessment of the severity of chronic hepatitis $\mathrm{C}$ and the prediction of response to therapy. Rom J Gastroenterol 2002; 11: 97-103.

123.Larrea E., Garcia N., Qian C., et al. Tumor necrosis factor alpha gene expression and the response to interferon in chronic hepatitis C. Hepatology 1996; 23: $210-7$.

124.Zein N.N. Etanercept as an adjuvant to interferon and ribavirin in treatment-naive patients with chronic hepatitis $C$ virus infection: a phase 2 randomized, double-blind, placebocontrolled study. J Hepatol 2005; 42: 315-22.

125.Marinos G., Naoumov N.V., Rossol S., et al. Tumor necrosis factor receptors in patients with chronic hepatitis B virus infection. Gastroenterology 1995; 108: 1453-63.

126.Deutsch M., Hadziyannis S.J. Old and emerging therapies in chronic hepatitis C: an update. J Viral Hepat 2008; 15: 211. 